\title{
IMPACT OF CURCUMIN AND VIRGIN OLIVE OIL AGAINST LEAD ACETATE-INDUCED GENETIC VARIATION IN THE MAJOR HISTOCOMPATIBILITY COMPLEX REGION IN MICE
}

\author{
Mohammad Allam ${ }^{1 *}$; Fayza M. Aly ${ }^{1}$; Zeinab A. Mar'ie ${ }^{1,2}$ \\ ${ }^{1}$ Zoology Department, Faculty of Science, South Valley University, Qena, Egypt \\ ${ }^{2}$ Science Department, Faculty of Education, South Valley University, Hurghada, Red Sea, \\ Egypt
}

\author{
Article History: \\ Received: 28 July 2021 \\ Revised: 20 August 2021 \\ Accepted: 24 August 2021 \\ Published Online: \\ 6 September 2021 \\ Keywords: \\ Curcumin \\ Genetic variation \\ Lead acetate \\ Mice $M h c$ \\ Virgin olive oil

\section{*Correspondence:} \\ Mohammad Allam \\ Zoology Department \\ Faculty of Science \\ South Valley University \\ Qena, Egypt \\ E-mail: \\ Mohammad_allam10@sci. \\ svu.edu.eg
}

\begin{abstract}
Lead acetate - which results in significant damage to the genetic structure of living organisms - is found in many sources that humans use daily. Histocompatibility complex $(M H C)$ genes in the vertebrate play a critical role in immune responses, and are highly polymorphic. Virgin olive oil (VOO) and curcumin are natural compounds having several healthy features including antigenotoxic activities. The present study aimed for determining the effects of $\mathrm{VOO}$ and curcumin (versus $\mathrm{ZnCl}_{2}$, as an antioxidant agent) on $M h c$ genetic variation of renal tissues of lead acetate-treated mice by using the microsatellite loci. Thirty male albino Swiss mice (Mus musculus) were randomly allotted into 5 groups $(\mathrm{n}=6)$ : group " 1 ", the control group; groups " $2-5$ " that received orally lead acetate $(400 \mathrm{mg} / \mathrm{kg}$ body weight, by gavage for 15 consecutive days) + either distilled water (orally), or $\mathrm{ZnCl}_{2}$ (4 mg/kg body weight, intraperitoneally injected), or curcumin $(500 \mathrm{mg} / \mathrm{kg}$ body weight, orally), or $\mathrm{VOO}(8 \mathrm{~mL} / \mathrm{kg}$ body weight, orally) for additional 15 consecutive days, respectively. Comparing to the control group, the $2^{\text {nd }}$ and the $4^{\text {th }}$ groups showed high polymorphism value (17\%) and (21\%), respectively; while the $3^{\text {rd }}$ and $5^{\text {th }}$ groups showed low polymorphism value $(12 \%)$ and $(15 \%)$, respectively, in $M h c$ genes. The obtained data illustrated the usefulness of virgin olive oil, as compared with the curcumin, in limiting $M h c$ genetic variation induced by lead acetate in mice.
\end{abstract}

\section{INTRODUCTION}

Lead acetate is a white crystalline toxic chemical compound with a slightly sweet taste, soluble in water and glycerin, and poorly soluble in alcohol ${ }^{[1]}$. Humans exposed daily to lead acetate sources, such as car fuel, dyes, preserved food in metal cans, water pipes, and some children toys ${ }^{[2,3]}$. Depending on the period of exposure, lead may enter the body through the skin, mouth, and nose causing a large toxicity ${ }^{[4,5]}$. Damage to many organs inside the body, as heart, liver, kidneys, brain, and testes could causes death due to the exposure to large amounts of lead acetate ${ }^{[6-9]}$. Zinc is famed as an antioxidant agent, where it has the ability to decrease membrane lipid peroxidation, and hence protecting from 
organ injury caused by oxidative stress ${ }^{[10,11]}$. In addition, it decreases $\mathrm{Pb}$ intoxication ${ }^{[11-13]}$.

Turmeric (Curcuma longa) has a yellow color fraction in its rhizome called curcumin, which has anti-inflammatory, anticarcinogenesis, and antioxidant activities ${ }^{[14,15]}$. Curcumin reduces the oxidative effect of lead ions by preventing its accumulation in different tissues, resulting in an improvement of serum biochemical parameters, reducing inflammation, protecting the cells from damage, and repairing it ${ }^{[16]}$.

Virgin olive oil is a successful dietary manipulation due to its unique features, by having high content of oleic acid and antioxidant molecules specially phenolic compounds $^{[17]}$. Salvini et $a l^{[18]}$ and Machowetz et al.$^{[19]}$ illustrated the protective role of olive oil against DNA damage; in addition, its antioxidant features lowering cancer incidence. The role of olive oil in reducing the toxicity of lead acetate in the experimental animals needs more investigations $^{[20]}$.

Microsatellites are useful for discriminating alleles at single loci in the $M h c$ region of mice ${ }^{[21]}$. The genotypes at three linked microsatellite loci were identical in a sample of humans sharing the same $M H C$ haplotype, so it may be useful for distinguishing distinct $M H C$ haplotypes ${ }^{[22]}$. Dietrich et $a l .{ }^{[23]}$ reported that the Mhc genes affect immunological mechanisms, parasite resistance, and mate choice; this information comes from the recent description of over 7000 microsatellites for Mus. The present study aimed to investigate the roles of curcumin and olive oil (versus zinc chloride) against the genetic variation-induced by lead acetate in $M h c$ region of mice.

\section{MATERIAL AND METHODS Chemicals and natural products}

Lead acetate 3-hydrate powder $\left[\mathrm{CH}_{3} \mathrm{COO}\right)_{2} \mathrm{~Pb} \quad 3 \mathrm{H}_{2} \mathrm{O}$, purity: $98 \%$, manufactured by Rankem] and zinc chloride anhydrous $\left(\mathrm{ZnCl}_{2}\right.$, purity $98 \%$, manufactured by Apollo Scientific) were obtained from Gene Tech, Cairo, Egypt. Pure curcumin powder was obtained from
Health and Food Store, Giza, Egypt. Virgin olive oil (VOO, 100\% natural, cold pressed, acidity: $<0.8 \%$ ) was obtained from Isis Co, Cairo, Egypt.

\section{Animals}

Thirty male albino Swiss mice (Mus musculus), about 6-8 weeks old and weighing $23 \pm 2 \mathrm{~g}$, were obtained from College of Veterinary, South Valley University, Qena, Egypt. The animals were kept in cages in animal's house for two weeks, for acclimatization to laboratory conditions before the start of the experiments, and were given free access daily to water and rodent food pellets.

\section{Experiment design}

Mice were randomly allotted into 5 groups $(\mathrm{n}=6)$ : group "1", the control group; groups " $2-5$ " that received lead acetate (400 mg/kg body weight, orally by gavage for 15 consecutive days) + either distilled water (orally), or $\mathrm{ZnCl}_{2}$ (4 $\mathrm{mg} / \mathrm{kg}$ body weight, as an antioxidant agent, intraperitoneal injection ${ }^{[24]}$, or curcumin (500 mg/kg body weight, orally ${ }^{[25]}$ ), or VOO ( $8 \mathrm{~mL} / \mathrm{kg}$ body weight, orally ${ }^{[26]}$ ) for additional 15 consecutive days, respectively. The lead acetate dose was determined according to our preliminary experimental. All mice were killed 24 hours after the last dose. The kidneys were rapidly removed and stored in $-20^{\circ} \mathrm{C}$ until used for DNA extraction.

\section{DNA Extraction}

DNA was extracted from the preserved renal tissues using the DNA extraction method of QIAamp DNA Mini kit (Qiagen, Hidden, Germany) by following the manufacturer's guidelines.

\section{Microsatellite loci}

After the extraction of DNA, a set of seven microsatellite loci closely linked to the Mhc genes was used (Table 1). These microsatellites lie between 18.00 and 19.50 centimorgan from the centromere of chromosome 17 and are located within the conventional $\mathrm{H}-2$ region (bounded by the $\mathrm{K}$ and $\mathrm{L}$ genes), where most of the highly 
polymorphic antigen-presenting $M h c$ loci are found ${ }^{[27]}$. The polymerase chain reaction (PCR) amplification was done using a total volume of $20 \mu \mathrm{L}$ containing $10 \mu \mathrm{L}$ of PCR master mix (OnePCR ${ }^{\mathrm{TM}}$ readyto-use, catalogue number: MB203-0100, GeneDireX, Miaoli County, Taiwan), $0.5 \mu \mathrm{L}$ of each forward and reverse primer $(10 \mathrm{pmol} / \mu \mathrm{L}), 8 \mu \mathrm{L}$ of nuclease-free water, and $1 \mu \mathrm{L}$ genomic DNA as a template. The PCR amplification conditions were: initial denaturation at $95^{\circ} \mathrm{C}$ for $180 \mathrm{~s}$, then 30 cycles each one containing denaturation at $94^{\circ} \mathrm{C}$ for $60 \mathrm{~s}$, annealing for $60 \mathrm{~s}$ at primer specific temperature $\left(50^{\circ} \mathrm{C}\right.$ for D17Mit21, $53^{\circ} \mathrm{C}$ for D17Mit214, $55^{\circ} \mathrm{C}$ for D17Mit28, D17Mit83, and D17Mit103, $56^{\circ} \mathrm{C}$ for D17Mit33, and $57^{\circ} \mathrm{C}$ for $\mathrm{D} 17 \mathrm{Nds} 3), 7^{\circ} \mathrm{C}$ for $60 \mathrm{~s}$ for extension, followed by a final extension at $72^{\circ} \mathrm{C}$ for 7 minutes. After PCR amplification, The PCR products and 100bp DNA Ladder ready-to-use (Catalogue Number: DM001R500, GeneDireX) were electrophoresed on $1.5 \%$ agarose gel stained with ethidium bromide at 80 volts for 2-3 hours. Expected heterozygosity (HE), polymorphic information content (PIC), average heterozygosity (H.av), marker index (MI) were evaluated by online marker efficiency calculator $\mathrm{iMEC}^{[28]}$. The genetic similarity and dendrogram were calculated by palentological statistics (PAST) software version $2.17 \mathrm{c}^{[29]}$.

Table 1: Primers, total of alleles (TA), monomorphic alleles (MA), polymorphic allele (PA), $\%$ polymorphic $(\% \mathrm{P})$, Frequency $(\mathrm{F})$, expected heterozygosity $(\mathrm{HE})$, polymorphic information content (PIC), average heterozygosity (H.av), marker index (MI).

\begin{tabular}{lccccccccc}
\hline \multicolumn{1}{c}{ Primer } & TA & MA & PA & $\%$ P & F & HE & PIC & H.av & MI \\
\hline D17Mit21 & 15 & 4 & 11 & 73 & 0.6 & 0.45 & 0.35 & 0.0080 & 0.0211 \\
D17Mit28 & 17 & 13 & 4 & 24 & 0.9 & 0.36 & 0.30 & 0.0050 & 0.0153 \\
D17Mit83 & 9 & 2 & 7 & 78 & 0.7 & 0.47 & 0.36 & 0.0146 & 0.0366 \\
D17MitNds3 & 9 & 6 & 3 & 33 & 0.9 & 0.26 & 0.23 & 0.0082 & 0.0278 \\
D17Mit214 & 9 & 3 & 6 & 67 & 0.6 & 0.47 & 0.36 & 0.0146 & 0.0366 \\
D17Mit33 & 8 & 5 & 3 & 38 & 0.9 & 0.34 & 0.28 & 0.0120 & 0.0377 \\
D17Mit103 & 7 & 0 & 7 & 100 & 0.8 & 0.47 & 0.36 & 0.0195 & 0.0488 \\
Mean & 10.6 & 4.7 & 5.9 & 59 & 0.8 & 0.40 & 0.32 & 0.0117 & 0.0319 \\
\hline
\end{tabular}

\section{RESULTS}

The results revealed that the number of alleles ranged from 7 to 17 in all groups (Table 1). From the seven used microsatellites, D17Mit21 and D17Mit28 showed the highest number of alleles. On the contrary of that, D17Mit103 display a smaller number of alleles. The maximum number of alleles was obtained in D17Mit28 locus, and the minimum number of alleles was found in D17Mit103 locus. The mean of observed number of alleles for all the loci was 10.6. The maximum expected heterozygosity (0.47) was obtained in D17Mit83, D17Mit214, and D17Mit103, and the minimum expected heterozygosity was in
D17MitNds3 as 0.26 with a mean of 0.40 for all loci. The PIC values ranged from 0.23 in D17MitNds3 to 0.36 in D17Mit83, D17Mit214, and D17Mit103. The mean of PIC value was 0.32 . Average heterozygosity was measured maximum in the marker D17Mit103 (0.0195) and minimum in D17Mit28 (0.0050) with a mean of 0.0177 . The MI values among the 7 microsatellite loci ranged from 0.0153 (D17Mit28) to 0.0488 (D17Mit103), and the average value of MI was 0.0319 (Table 1). More details about the number of alleles, monomorphic alleles, and polymorphic alleles in the four groups comparing to the control group were given in (Table 2). 
Table 2: Number of alleles (NA), monomorphic alleles (MA), and polymorphic allele (PA) in the four tested groups comparing to the control group.

\begin{tabular}{|c|c|c|c|c|c|c|c|c|c|c|c|c|c|}
\hline \multirow[t]{2}{*}{ Primer } & \multirow{2}{*}{$\frac{\text { Control }}{\text { NA }}$} & \multicolumn{3}{|c|}{ Lead acetate } & \multicolumn{3}{|c|}{$\begin{array}{l}\text { Lead acetate } \\
+\mathrm{ZnCl}_{2}\end{array}$} & \multicolumn{3}{|c|}{$\begin{array}{l}\text { Lead acetate } \\
+ \text { Curcumin }\end{array}$} & \multicolumn{3}{|c|}{$\begin{array}{l}\text { Lead acetate } \\
+ \text { VOO }\end{array}$} \\
\hline & & NA & MA & PA & $\mathrm{NA}$ & MA & PA & NA & MA & PA & NA & MA & $\mathrm{PA}$ \\
\hline D17Mit21 & 9 & 10 & 14 & 5 & 11 & 18 & 2 & 11 & 14 & 6 & 7 & 10 & 6 \\
\hline D17Mit28 & 15 & 14 & 28 & 1 & 15 & 30 & 0 & 16 & 28 & 3 & 14 & 26 & 3 \\
\hline D17Mit83 & 8 & 6 & 12 & 2 & 5 & 10 & 3 & 6 & 10 & 4 & 6 & 10 & 4 \\
\hline D17MitNds3 & 9 & 8 & 16 & 1 & 7 & 14 & 2 & 7 & 14 & 2 & 9 & 8 & 0 \\
\hline D17Mit214 & 6 & 5 & 6 & 5 & 3 & 6 & 3 & 8 & 10 & 4 & 5 & 8 & 3 \\
\hline D17Mit33 & 8 & 5 & 10 & 3 & 6 & 12 & 2 & 7 & 14 & 1 & 8 & 8 & 0 \\
\hline D17Mit103 & 5 & 5 & 8 & 2 & 5 & 8 & 2 & 2 & 2 & 5 & 6 & 10 & 1 \\
\hline Sum & 60 & 53 & 94 & 19 & 52 & 98 & 14 & 57 & 92 & 25 & 55 & 80 & 17 \\
\hline
\end{tabular}

VOO: virgin olive oil.

The genetic similarity of the five groups was calculated by PAST software. Comparing to the control group, the lead acetate- and the lead acetate+curcumintreated groups showed highly polymorphism value $(17 \%)$ and (21\%), respectively, while lead acetate $+\mathrm{ZnCl}_{2^{-}}$and lead acetate+VOO-treated groups showed low polymorphism value $(12 \%)$ and (15\%), respectively (Table 3$)$. The dendrogram consisted of two main groups (Figure 1). The first main group encloses one group, the $4^{\text {th }}$ group (lead acetate+ curcumin-treated group). The second main group includes all the remaining groups.

Table 3: The similarity matrix UPGMA Jaccard's coefficient among the five groups. Group "1": the control group, group "2": lead acetate-treated group, group " 3 " lead acetate $+\mathrm{ZnCl}_{2^{-}}$ treated group, group " 4 ": lead acetate+curcumin-treated group, group " 5 " lead acetate+virgin olive oil-treated group.

\begin{tabular}{lccccc}
\hline & Group 1 & Group 2 & Group 3 & Group 4 & Group 5 \\
\hline Group 1 & $100 \%$ & & & & \\
Group 2 & $83 \%$ & $100 \%$ & & & \\
Group 3 & $88 \%$ & $85 \%$ & $100 \%$ & & \\
Group 4 & $79 \%$ & $78 \%$ & $75 \%$ & $100 \%$ & \\
Group 5 & $85 \%$ & $80 \%$ & $80 \%$ & $77 \%$ & $100 \%$ \\
\hline
\end{tabular}
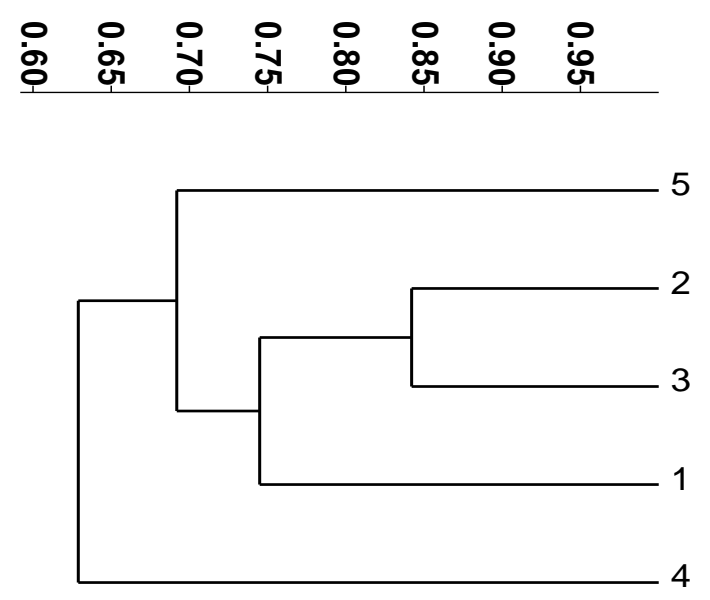

Figure 1. Dendrogram demonstrating the relationship among the five groups based on data recorded from Microsatellite. 1: The control group, 2: lead acetate-treated group, 3: lead acetate $+\mathrm{ZnCl}_{2}$-treated group, 4: lead acetate+curcumin-treated group, 5: lead acetate+virgin olive oil-treated group. 


\section{DISCUSSION}

It can be said that the $M H C$ region has been recognized as the region of the genome with the largest number of human disease associations $^{[30]}$. The $M h c$ genomic region in the mouse was located on chromosome $17^{[31]}$. In the current study, we used seven microsatellites situated between the $\mathrm{K}$ and $\mathrm{D}$ locus on chromosome 17 because this region contains the highest number of alleles. In $M$. domestics strains, the average number of alleles found between the $\mathrm{K}$ and $\mathrm{D}$ loci is higher than those loci either near or away from this region ${ }^{[27]}$.

Our finding of microsatellite revealed that lead acetate caused genetic variation in the Mhc loci especially D17Mit214 locus, where polymorphism was $45.45 \%$, comparing to the control group. The total number of alleles in both control and lead acetate groups was 113 . Out of them 19 were polymorphic alleles (17\% polymorphism). This finding agrees with several researches proved the harmful effect of lead on DNA. Snow ${ }^{[32]}$ reported that the genotoxic effects could be the result of many mechanisms, like the inhibition of DNA metabolism, the induction of cellular immunity and oxidative stress, and the formation of DNA and/or protein cross-links. Furthermore, Acharya et $a l .{ }^{[33]}$ reported that lead ions are believed to reduce the fidelity of DNA synthesis. Some indirect mechanisms by lead also induced reactive oxygen species (ROS) and can inhibit DNA polymerase B, which possibly pointing to the failure of DNA repair mechanisms. Also, Gargioni et al. ${ }^{[34]}$ observed damage effect of lead on DNA of mice, that is because of the direct effect of lead on the DNA structure and oxidative mechanisms $^{[35]}$. Ibrahim ${ }^{[36]}$ indicated the sensitivity of microsatellite sequences located at the fragile sites at D6mit3, D9mit2, and D15Mgh1 loci, as well as the sensitivity of the simple sequence repeats assay for the detection of small variations in DNA sequence in rats, after exposure to four heavy metals including lead acetate.

The total number of alleles in both control and lead acetate $+\mathrm{ZnCl}_{2}$-treated groups was 112. Out of them 14 were polymorphic alleles (13\% polymorphism). These results indicated that zinc chloride has a positive effect against lead acetateinduced $M h c$ genetic variation. Grüngreiff ${ }^{[37]}$ also reported that zinc is involved in several important biological processes such as cell division, growth, and differentiation, as well as it protects the DNA strand from damage.

The total number of all alleles in control and lead acetate+curcumin-treated groups was 117 . Out of them 25 were polymorphic alleles (21\% polymorphism). These results indicate that the curcumin did not improve the genetics effect of lead acetate, but it increased the genetic polymorphism comparing to the control group. Mukhopadhyay et al. ${ }^{[38]}$ reported the slight increase in the number of chromosomal aberrations in acutely treated mice by curcumin. Curcumin increased both the number of abnormal metaphase and the frequency of chromosomal aberration at the highest concentration in Chinese hamster ovary cell lines and did not prevent bleomycin-induced chromosomal damage in any phases of the cell cycle $^{[39]}$. Morimoto et al. ${ }^{[40]}$ concluded that curcumin inhibited the hypertrophy-induced acetylation and DNA-binding abilities of a hypertrophy responsive transcription factor "GATA4" in rat cardiomyocyte, indicating that inhibition of histone acetyltransferase p300 (p300 HAT) activity by curcumin may also provide a novel therapeutic strategy for heart failure in humans. Curcumin induces epigenetic changes, and has effects on the regulation of histone deacetylases, histone acetyl transferases, DNA methyl transferase I, and mi RNAs ${ }^{[41]}$.

In the lead acetate+VOO-treated group, olive oil reduced the harmful genetic effect of lead acetate on the $M h c$ genes in mice, where the genetic similarity was $85 \%$, while the polymorphism was $15 \%$, i.e. better than that in the lead acetate+curcumin-treated group. This may be due to that curcumin displays low oral bioavailability because of its poorly absorption by small intestine, coupled to an extensive reductive associated 
with metabolism in the liver and an elimination through the gall bladder ${ }^{[42,43]}$. On the other hand, olive oil contains a high concentration of antioxidant compounds, involving phenolic compounds. The antioxidant activities of the phenolic compounds have the ability to protect DNA, proteins, and lipids from damage caused by exposure to $\operatorname{ROS}^{[44]}$. Reducing oxidative stress by olive oil was probably related to the activities of its phenolic compounds (especially oleuropein and hydroxytyrosol) as strong free-radical scavengers and metal chelators. Oleuropein and hydroxytyrosol possess a catechol group, which is essential for their scavenging activity of hydroxyl radicals and superoxide anions ${ }^{[45]}$. In this sense, virgin olive oil may thus be important component of effective dietary manipulations aimed to partially modify the structure, and the features, of biological membranes in the daily conflict against free radicals and oxidative stress-induced damage ${ }^{[17]}$. Fabiani et $a l .^{[46]}$, showed a potent DNA damage preventive activity of olive oil phenols, providing new evidence to support a possible role of these compounds in the prevention of cancer.

In conclusion, using the microsatellite loci linked to $M h c$ genes in the determination of the genetic variation in $M h c$ region in mice, which caused by lead acetate, is useful. The data of the present study illustrated the beneficial effects of $\mathrm{VOO}$, in contrast to curcumin, against lead acetate-induced $M h c$ genetic variation in mice. The current study may encourage the using of VOO as foodadjunct to inhibit the harmful genetic effects of lead.

\section{COMPLIANCE WITH ETHICAL STANDARDS}

All experimentation and care of the animals used in this study were in compliance with the Faculty of Science, South Valley University's policy on animal use and ethics. All mandatory laboratory health and safety measures have been adhered while performing the experimental work of this study.

\section{FUNDING SOURCE DISCLOSURE}

This research received no specific grant from any funding agency in the public, commercial, or not-for-profit sectors.

\section{CONFLICT OF INTEREST}

The authors have no potential financial conflict of interest.

\section{REFERENCES}

[1] Zhang, H.; Hao, F and Liu, R. (2013). Interactions of lead (II) acetate with the enzyme lysozyme: a spectroscopic investigation. J Lumin, 142: 144-149.

[2] Ashraf, U.; Kanu, A. S.; Mo, Z. et al. (2015). Lead toxicity in rice: effects, mechanisms, and mitigation strategies-a mini review. Environ Sci Pollut Res Int, 22(23): 18318-18332.

[3] Fouad, A. A.; Foda, N. T.; Diab, I. H. et al. (2020). Evaluation of possible molecular toxicity induced by occupational exposure to lead and concomitant effect of smoking. Environ Sci Pollut Res Int, 27(1): 411423.

[4] Meyer, P. A.; Brown, M. J. and Falk, H. (2008). Global approach to reducing lead exposure and poisoning. Mutat Res, 659(1-2): 166-175.

[5] Rerknimitr, P.; Kantikosum, K.; Chottawornsak, N. et al. (2019). Chronic occupational exposure to lead leads to significant mucocutaneous changes in lead factory workers. J Eur Acad Dermatol Venereol, 33(10): 1993-2000.

[6] Patra, R. C.; Rautray, A. K. and Swarup, D. (2011). Oxidative stress in lead and cadmium toxicity and its amelioration. Vet Med Int, 2011: 457327 (DOI: 10.4061/2011/457327).

[7] Toscano, C. D. and Guilarte, T. R. (2005). Lead neurotoxicity: from exposure to molecular effects. Brain Res Brain Res Rev, 49(3): 529-554.

[8] Zhang, Y.; Li, Q.; Liu, X. et al. (2013). Antioxidant and micronutrient-rich milk formula reduces lead poisoning and related oxidative damage in lead- 
exposed mice. Food Chem Toxicol, 57: 201-208.

[9] Abdelhamid, F. M.; Mahgoub, H. A. and Ateya, A. I. (2020). Ameliorative effect of curcumin against lead acetate-induced hemato-biochemical alterations, hepatotoxicity, and testicular oxidative damage in rats. Environ Sci Pollut Res Int, 27(10): 10950-10965.

[10] Formigari, A.; Irato, P. and Santon, A. (2007). Zinc, antioxidant systems and metallothionein in metal mediatedapoptosis: biochemical and cytochemical aspects. Comp Biochem Physiol C Toxicol Pharmacol, 146(4): 443-459.

[11] Malekirad, A. A.; Oryan, S.; Fani, A. et al. (2010). Study on clinical and biochemical toxicity biomarkers in a zinc-lead mine workers. Toxicol Ind Health, 26(6): 331-337.

[12] Gurer, H. and Ercal, N. (2000). Can antioxidants be beneficial in the treatment of lead poisoning? Free Radic Biol Med, 29: 927-945.

[13] Kulikowska-Karpinska, E. and Moniuszko-Jakoniuk, J. (2001). Lead and zinc influence on antioxidant enzyme activity and malondialdehyde concentrations. Pol J Environ Stud, 10(3): 161-165.

[14] Singh, S. (2007). From exotic spice to modern drug? Cell, 130(5): 765-768.

[15] Zhang, Y.; Cao, H.; Yu, Z. et al. (2013). Curcumin inhibits endometriosis endometrial cells by reducing estradiol production. Iran $\mathbf{J}$ Reprod Med, 11(5): 415-422.

[16] Soliman, M. M.; Baiomy, A. A. and Yassin, M. H. (2015). Molecular and histopathological study on the ameliorative effects of curcumin against lead acetate-induced hepatotoxicity and nephrototoxicity in Wistar rats. Biol Trace Elem Res, 167(1): 91102.

[17] Quiles, J. L.; Barja, G.; Battino, M. et al. (2006). Role of olive oil and monounsaturated fatty acids in mitochondrial oxidative stress and aging. Nutr Rev, 64: S31-S39.

[18] Salvini, S.; Sera, F.; Caruso, D. et al. (2006). Daily consumption of a highphenol extra-virgin olive oil reduces oxidative DNA damage in postmenopausal women. Br J Nutr, 95(4): 742-751.

[19] Machowetz, A.; Poulsen, H. E.; Gruendel, S. et al. (2007). Effect of olive oils on biomarkers of oxidative DNA stress in Northern and Southern Europeans. FASEB J, 21(1): 45-52.

[20] Ashour, A. A.; Yassin, M. M.; Abu Aasi, N. M. et al. (2007). Blood, serum glucose and renal parameters in lead-loaded albino rats and treatment with some chelating agents and natural oils. Turk J Biol, 31: 25-34.

[21] Saha, B. K.; Shields, J. J.; Miller, R. D. et al. (1993). A highly polymorphic microsatellite in the class II $E b$ gene allows tracing of major histocompatibility complex evolution in mouse. Proc Natl Acad Sci U S A, 90(11): 5312-5316.

[22] Crouau-Roy, B.; Bouzekri, N.; Carcassi, C. et al. (1996). Strong association between microsatellites and an HLA-B, DR haplotype (B18-DR3): implication for microsatellite evolution. Immunogenetics, 43(5): 255-260.

[23] Dietrich, W. F.; Miller, J.; Steen, R. et al. (1996). A comprehensive genetic map of the mouse genome. Nature, 380(6570): 149-152.

[24] Ayhanci, A.; Uyar, R.; Aral, E. et al. (2008). Protective effect of zinc on cyclophosphamide-induced hematoxicity and urotoxicity. Biol Trace Elem Res, 126(1-3): 186-193.

[25] Pandey, G. (2011). Active principles and median lethal dose of Curcuma longa Linn. Int Res J Pharm, 2(5): 239-241.

[26] Osman, W. A.; Labib, D. A.; Abdelhalim, M. O. et al. (2017). Synergistic analgesic, anti-pyretic and anti-inflammatory effects of extra 
virgin olive oil and ibuprofen in different experimental models of albino mice. Int J Rheum Dis, 20(10): 1326-1336.

[27] Meagher, S. and Potts, W. K. (1997). A microsatellite-based Mhc genotyping system for house mice (Mus domesticus). Hereditas, 127(1-2): 75-82.

[28] Amiryousefi, A.; Hyvönen, J. and Poczai, P. (2018). iMEC: online marker efficiency calculator. Appl Plant Sci, 6(6): e01159 (DOI: 10.1002/ aps3.1159).

[29] Hammer, Ø.; Harper, D. A. T., and Ryan, P. D. (2001). PAST: paleontological statistics software package for education and data analysis. Palaeontologia Electronica, 4(1): 1-9 (https://palaeo-electronica. org/2001_1/past/issue1_01.htm).

[30] Trowsdale, J. and Knight, J. C. (2013). Major histocompatibility complex genomics and human disease. Annu Rev Genomics Hum Genet, 14: 301-323.

[31] Kumánovics, A. and Lindahl, K. F. (2004). Good copy, bad copy: choosing animal models for HLAlinked diseases. Curr Opin Genet Dev, 14(3): 258-263.

[32] Snow, E. T. (1992). Metal carcinogenesis: mechanistic implications. Pharmacol Ther, 53(1): 31-65.

[33] Acharya, U. R.; Acharya, S. and Mishra, M. (2003). Lead acetate induced cytotoxicity in male germinal cells of Swiss mice. Ind Health, 41(3): 291-294.

[34] Gargioni, R.; Filipak Neto, F.; Buchi, D. F. et al. (2006). Cell death and DNA damage in peritoneal macrophages of mice (Mus musculus) exposed to inorganic lead. Cell Biol Int, 30(7): 615-623.

[35] Stohs, S. J. and Bagchi, D. (1995). Oxidative mechanisms in the toxicity of metal ions. Free Radic Biol Med, 18(2): 321-336.

[36] Ibrahim, J. (2012). Microsatellite
Instability within Fragile Sites in the Rat Genome: : MSI Induced by Heavy Metals. LAP LAMBERT Academic Publishing, Chișinău, Republic of Moldova.

[37] Grüngreiff, K. (2016). Zinc deficiency and liver diseases-general observations. SM J Hepat Res Treat, 2: 1008 (DOI: 10.36876/smjhrt.1008).

[38] Mukhopadhyay, M. J.; Saha, A. and Mukherjee, A. (1998). Studies on the anticlastogenic effect of turmeric and curcumin on cyclophosphamide and mitomycin $\mathrm{C}$ in vivo. Food Chem Toxicol, 36: 73-76.

[39] Araújo, M. C. P.; Dias, F. da L.; Kronka, S. N. et al. (1999). Effects of turmeric and its active principle, curcumin, on bleomycin-induced chromosome aberrations in Chinese hamster ovary cells. Genet Mol Biol, 22(3): 407-413.

[40] Morimoto, T.; Sunagawa, Y.; Kawamura, T. et al. (2008). The dietary compound curcumin inhibits p300 histone acetyltransferase activity and prevents heart failure in rats. J Clin Invest, 118(3): 868-878.

[41] Reuter, S.; Gupta, S. C.; Park, B. et al. (2011). Epigenetic changes induced by curcumin and other natural compounds. Genes Nutr, 6(2): 93-108.

[42] Heger, M.; van Golen, R. F.; Broekgaarden, M. et al. (2014). The molecular basis for the pharmacokinetics and pharmacodynamics of curcumin and its metabolites in relation to cancer. Pharmacol Rev, 66(1): 222-307.

[43] Dei Cas, M. and Ghidoni, R. (2019). Dietary Curcumin: correlation between bioavailability and health potential. Nutrients, 11(9): 2147 (DOI: 10.3390/ nu11092147).

[44] Fki, I.; Sahnoun, Z. and Sayadi, S. (2007). Hypocholesterolemic effects of phenolic extracts and purified hydroxytyrosol recovered from olive mill wastewater in rats fed a cholesterol-rich diet. J Agric Food 
Chem, 55(3): 624-631.

[45] Visioli, F.; Poli, A. and Gall, C. (2002). Antioxidant and other biological activities of phenols from olives and olive oil. Med Res Rev, 22: 65-75.

[46] Fabiani, R.; Rosignoli, P.; De
Bartolomeo, A. et al. (2008). Oxidative DNA damage is prevented by extracts of olive oil, hydroxyltyrosol, and other olive phenolic compounds in human blood mononuclear cells and HL60 cells. J Nutr, 138(8): 1411-1416.

\section{How to cite this article:}

Allam, M.; Aly, F. M.; Marie, Z. A. (2021). Impact of curcumin and virgin olive oil against lead acetate-induced genetic variation in the major histocompatibility complex region in mice. Egyptian Journal of Zoology, 76: 66-75 (DOI: 10.21608/ejz.2021.88079.1063). 


\section{تأثير الكركمين وزيت الزيتون البكر علي التباين الجيني المُستحث بخلات الرصاص فئواص

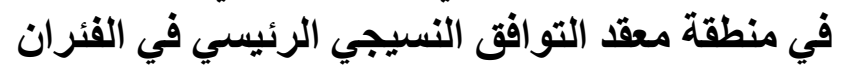

\section{محمد علام1، فايزة محمد علي1، زينب عبد الخالق مرعي21،}

1قسم علم الحيو ان، كلية العلوم، جامعة جنوب الوادي، قنا، جمهورية مصر العربية

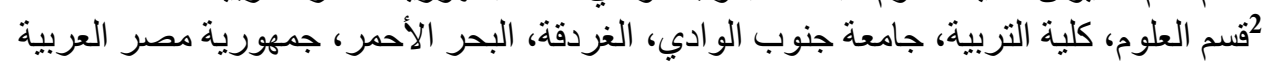

يوجد خلات الرصاص - الذي ينتج عنه ضرر كبير للبنية الجينية للكائنات الحية - في العديد من المصادر التي يستخدمها

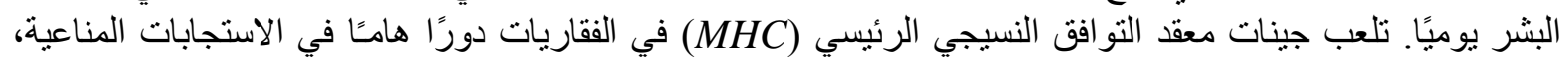

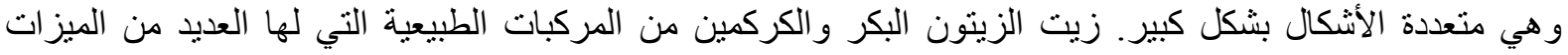

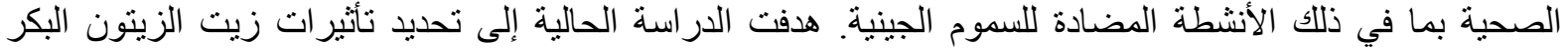

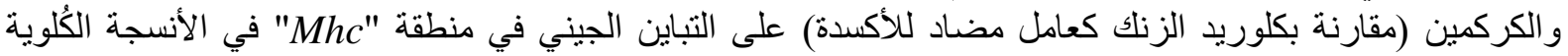

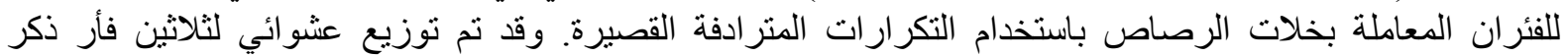

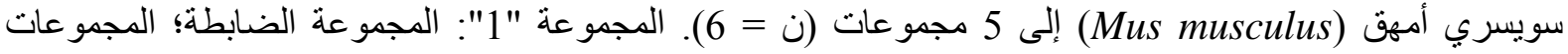

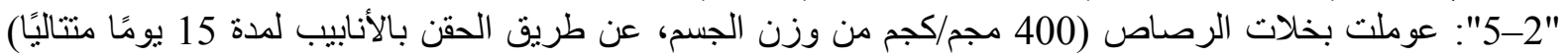

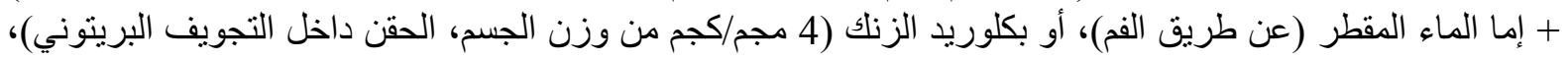

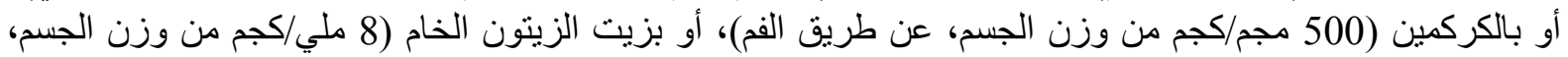

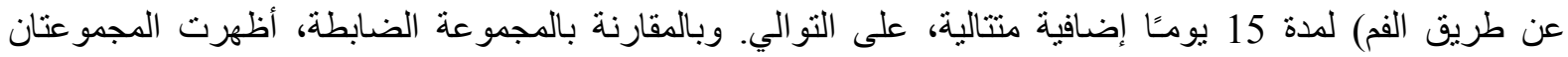

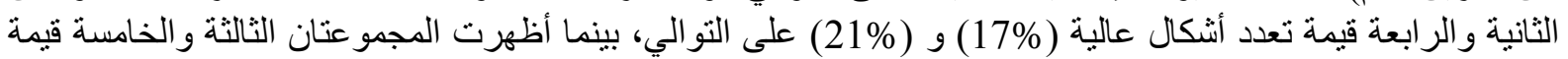

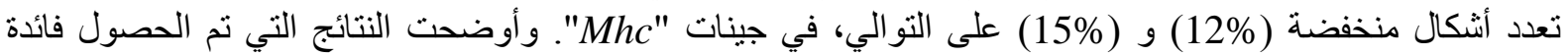

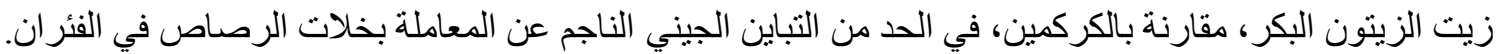

